\title{
The Significance of Metaphysical Presuppositions in Yoruba Punitive System
}

\author{
Adebayo Aina*
}

\section{Abstract}

Within the notion of punishment in the Yoruba culture, the physical and non-physical aspects of human existence are reconciled to arrive at a justifiable punitive action. The metaphysical presuppositions in Yoruba punitive system reflect a coherent interconnection among social structure, law and belief system for the harmonious human wellbeing of the individual and the community. The judicious imposition of punitive measures on the offender establishes the significance of responsibility for every human action without antagonism. But, the offender, within the tradition, is restitutively reconciled with himself, the victim and the community at large. The social order based on these principles creates and modifies the contemporary understanding of penology and penal practice.

Keywords: Adjudication, Metaphysics, Ontology, Punishment, Yoruba Culture

\section{Introduction}

Individuals who constitute a society are contractually bound together to share joys and concerns in a cooperative manner. This social order enables people to work together for common purposes and to pursue their personal lives in a peaceful and harmonious manner. However, where an individual fails to comply with the

\footnotetext{
Olabisi Onabanjo University, PMB 2002 Ago-Iwoye, Nigeria;
} Bayo_kofo@yahoo.com 
cooperative commitment, the individual would be seen as exploiting others who deserve to be punished; the contractual agreement provides the framework for evaluating whether a social contract has been flouted. African thought system, specifically the Yoruba experiences, is no exception to this ideation of social cohesion. Such an ideation is informed by the underlying metaphysical presuppositions shared by members following the Yoruba tradition. Punishment in Yoruba thought is referred to as ijiyá, which may consist of flogging, whipping, beating, tying, chaining, imprisonment, execution, ejection or banishment, razing of the house of an offender to the ground, and so forth (Ajisafe, 1946, p. 36). It is facilitated by the socially defined sins (èse) which violate culturally defined norms and laws to engender the destruction of social harmony not only among the natural beings but also between the natural and spiritual realms of existence.

The paper attempts to understand the significance of metaphysical presuppositions in the punitive system of Yoruba culture. We begin with a discussion on the nature of metaphysical presuppositions in this tradition grounded on the relationship between spiritual and natural realms. Following the discussion, we attempt to demonstrate that in the punitive system, the spiritual realm plays an overarching role. Apart from assisting human beings in the organisation of reality, it also imposes a sanction on specific aspects of social morality in their natural existence. In conclusion, we offer an analysis of the implications of the metaphysical concerns in the punitive systems in contemporary societies.

\section{Metaphysical presuppositions in Yoruba culture}

Discussion of metaphysical presuppositions in Yoruba culture revolves around the ontological realm which aims to identify the ultimate cosmic principle by which things come into existence. The nature of these entities involves the relationship between two planes of existence: the spiritual and natural. According to the Ifá system, the spiritual (İsalu-O'run) is housed by supernatural forces including Olódumare (the Supreme Being), the Orisa (divinities), the Ajogun (anti-gods or malevolent gods), the Ajé (witches and wizard) and the ancestors while the natural world (İsalu'-A'yé) is the domain of human beings, animals and plants (Abimbola, 2006, p. 52). 
The Yoruba belief system takes Olo' dumare (the Supreme Being) as the controller and creator of all living things. That is, $\mathrm{He}$ is the originator and giver of life, and in that capacity He, is called Elémi (the owner of the spirit or the owner of life) (Idowu, 1996, p. 36). Alongside this belief is the attribute that Olodumare is according to the Yoruba saying, a 'oba a dake dajo' (The king who sits in silence and dispenses justice). It refers to the Yoruba belief that no wicked humankind will escape the judgement of Olódumarè. The outwardness of humankind and divinities alike do not escape his notice and judgement. It is expected that everyone will follow the dictate of Olódumaré, which ensures that the failure to conform will dispense punishment and the obeisance and performance of good acts will be rewarded. The Yoruba believe that right conduct leads to goodness and wrong behaviour leads to vice. Moreover, there is no annual ceremony for Him but His name is mentioned during ceremonies for the Orisa with such expression as Ki Olódumare gba à $\grave{a}$ [may Olódumarè accept it]. It implies that the O'risà (divinities) are mere intermediaries between Olódumarè and man.

The Olodumare, therefore, is the creator, the dependable one, eternal, infinite, all-causing being. There are, however, over one thousand, four hundred and forty (1440) Orisa (divinities) in Yoruba pantheon. Each of the Orisa is endowed with a specialised role to play in the life of mankind in the Yoruba belief system (Simpson, 1994, pp. 1-69). The Orisa are the spokesperson of Olódumarè. They derive their powers from the latter and use it independently of Him. They are nearer to mankind and that is why they demand for a definite cult. Each cult has their own ritual patterns. They are worshipped by men and those who default attract punishment. Sacrifices are made to them occasionally in appreciation for their kindness and material blessings.

Nevertheless, the Orisa are able to foretell the future, prevent evil as well as provide antidotes against sickness and ill-luck. People consult them for protection against mystery of life such as bad crops, poverty, misfortune and sterility. In this sense, they are important for the welfare of a community. For example, people depend on them in the time of war in order to achieve victory. Besides, whenever the community experiences an epidemic, people tend to consult the Orisa through sacrifices to seek relief. 
Furthermore, in the spiritual realm of existence, the Ajogun (antigods) are considered to be irredeemably malevolent. They wage war on both human beings and the O'risà. According to Abimbola (2006, p. 49), there are two hundred plus one $(200+1)$ of these forces in the universe. These forces are all separate and distinct entities, and as such they are individually responsible for a specific type of evil. The warlords are Iku' (death); A'run (Disease); Ofo (loss); Egba (paralysis); Òràn (Big-trouble); Epè (curse); Ëwon (imprisonment), Esse (affliction). Iku' is responsible for the final end of man's life. Arun is responsible for the affliction of man due to illness. Ofo involves the incessant destruction of man's property. Egba brings paralysis to man, and so forth. Ajogun are designated as man's enemies for they work against his interest at all time. But they can be appeased with sacrifices.

The Ajé ("witches") or İyámi (mysterious mother) is another form of supernatural power. They are beings with dual existences. That is, they have no permanent residence in both planes of existence. They use this power to serve as a cog in the wheel of human progress. They carry out these nefarious deeds by discomforting their victims. But the man makes effort to solve problems relating to these forces through consultation with an adept Ifá. It is the diviner who relates and reveals the source of the problem via witchcraft practice. In this sense, Ifá prescribes the object of sacrifice (perhaps propitiatory type) in order to appease the forces. Finally, the ancestors constitute the link between the spiritual world and the natural world. They are believed to intercede in the welfare of their descendants. In this sense, it could be disastrous for the community where the customs, traditions, ethics and activities left behind by the dead are neglected.

The natural world (İsalu'-ayé) houses human-beings, animals, and plants. Animals and plants are subservient to the whims and caprices of human beings. The ontology of a person in Yoruba belief system is, for the sake of clarity, divided into material and immaterial aspects (Oladipo, 1992, p. 15). According to Oladipo, the material element, Ara, refers both to the physical frame and other tangible material organs of a person. These include: Opolo (the brain), Okan, (the heart) and Ifun (the intestine) (Oladipo, 1992, pp. 15-16). Opolo and okin are said to be responsible for some conscious 
activities, such as thinking, feeling and so forth. Okan, on its part, is the basis of feeling and emotion. Finally, the Yoruba take Ifun to perform some psychical activities.

On the other hand, the category of the immaterial aspect of man includes Emí and Orí. Emí constitutes the invisible element responsible for the sustenance of life. It is 'closely associated with the breath and the whole mechanism of breathing which is its most expressive manifestation' (Oladipo, 1992, p. 19). The Yoruba believe that Emí is the sole responsibility of Olódumaré (the Supreme Being) to infuse breath in man after all the other physical parts have been completed by Orisanla (the arch divinity). On the other hand, Ori is the inner essence of a person. The Yoruba take it to be the creation of Olodimaré, who is responsible for instilling the inner sense in man. The extent of man's achievements depends on the type of Orí chosen in heaven. For example, one's Ori determines greatness in life. Similarly, the choice of good Orí assures a life of success and prosperity while that of a bad Ori fetches man failure in life. Thus, Ori is associated with human destiny and personality. Personality in this traditional Yoruba society depends on the extent to which man is responsible and accountable to both his/her family and society. As a result, man always endeavours in life to face these challenges and evolve his nature of being. In this belief system, the Yoruba recognise the importance of sacrifice as a means of rectifying or modifying an unalterable Ori chosen in heaven after several efforts to transform the original status of being. But the appeasement of Ori through sacrifice does not neglect the relevance of diligence since man exercises his/her freewill in his earthly existence, which incidentally carves the nature of his existence.

Makinde (1985) gives a resonant analysis of the relationship between Orí and moral responsibility. The strong sense of destiny, whereby once destiny is chosen, becomes impossible to be altered in real life. The weak sense of destiny claims that the chosen Ori can be altered either through some sacrificial ritual to ward off evil, or through performances that reveal the human effort to sustain the goodness of Orí (Makinde, 1985, pp. 62-65). Makinde questions the possibility of a strong destiny in the scheme of things in Yoruba society. In this sense, no person can be held responsible for his doing since he has been fated to do so. Even where a person blames 
O'rúnmila' for not influencing the initial allotment (İpin) to be a good one, he may respond. If a man is not directed to the correct way/path at the pre-natal state, then he may experience a situation whereby struggling in life and appeal or sacrifice to one's Orí becomes impossible. In the same vein, a person may be tempted to destroy a good Orí (Makinde, 1985, p. 64).

On the other hand, Makinde claims that the weak sense of destiny is possible because there is no logical reason to expect that every choice of a good Orí would lead to a successful life and every choice of a bad Orí to a complete failure' (Makinde, 1985, p. 64). This practical outlook recognises the sincerity with which the Yoruba take the issue of moral responsibility and punishment. For example, the Yoruba appraise people for their immoral behaviours, regardless of the nature of the chosen Orí. People are also praised not for their chosen destiny ascribed from heaven, but for maintaining the required standard of responsibility in the society. Thus, the weak sense of destiny is compatible with the spirit of freewill and moral responsibility and punishment, which the Yoruba strongly celebrate. In this sense, personality formation is communal because the latter is responsible either to modify or remodify; and through some appropriate sacrifices, a bad ori can be reconditioned, so to say, to become a good one. What is fundamental here is that the idea of punishment and moral responsibility hinge on the influence of the two planes of existence: Issalu-Ayé and İsalu'-Òrun.

Now, having clarified the entities constituting both the spiritual and natural planes of existence, it is pertinent to note that the relationship between these two realms is not exclusive in nature. Rather, the natural and spiritual planes of existence form the same continuum in Yoruba belief system. They regard the spiritual realm as essential to the welfare of man. As such, it is believed to provide the natural existence with a useful overarching system which assists a human being to organise reality and impose sanctions on his life. As noted in the discussion on the spiritual entities, this is effected through the people's religious beliefs. As a result of this, according to Sodipo (2004, p. 88),

its explanation must be given in terms of persons or entities that are like persons in significant respects. For it is an 
explanation like this that can reveal the motives that lay behind particular happenings; they alone answer the emotional question why the thing happened here, now and to me in particular.

Thus, mishaps based on observation and knowledge of natural processes without remedy are consigned to punishment by the supernatural forces. It is to say that the spiritual realm serves as "a means of resolving some of the significant puzzles of the human conditions" (Gbadegesin, 1984, p. 182). The inhabitant of the spiritual realm is endowed with extraordinary powers which cannot be perceived by man. It becomes imperative for man to continue to carry their favours for security and knowledge purposes. This is well summarised by Sodipo (2004, p. 89) thus:

The lorry driver who ties a charm to his lorry-seat and a magical object under the lorry's windscreen is not denying or trying to frustrate any of the general laws by which the motor-vehicle operates. He knows, as well as any scientific man, that if the brakes fail while the vehicle is moving at high speed there could be a serious accident. He is aware too that if the accident is serious enough, some of the passengers could die. But the general laws cannot answer for him the question where and when the brakes will fail, whether they would fail when the lorry is travelling at high or low speed and, should that happen, who of the passenger will be fatally wounded. The scientific man will push the application of general laws as far as it can go; after that chance takes over. But not so in Yoruba traditional thought. Even if a general law says that only one person out of a hundred passengers in a lorry involved in an accident would be saved the Yoruba believe that the gods, not chance, decide who that lucky one shall be and it is certainly worth trying to make oneself the lucky one through a charm or through the necessary sacrifice to some god or gods.

The Yoruba ascribe to the supreme being, Olódumarè, through the Orisa, those things for which they "cannot find naturalist explanation" (Oladipo, 1992, p. 49). However, three points, among others, may be raised from Sodipo's narrations. First, the Yoruba 
will attribute the ill fatedness of our traveller, out of helplessness, to the wish of the spiritual realm, perhaps Olódumare's sanctions. This is reflected in sayings like bo se yan ti e niyen (That is how he has chosen his portion from spiritual world) or ibi ti àyànmo e gbé é dé ni yèn (That is the extent of his chosen portion). Also, this may be the consequence of an inherited family curse. Sanctions of this nature might have evolved from the ill-treatment of fellow human beings in the time past. That is why the Yoruba say a' o be èse baba wo' lára omo (we shall revisit the father's punishment on the children). In short, the spiritual realm serves as a referent point for the Yoruba in their sustenance of the values of social solidarity, harmony and cooperation. In addition to this social role, the spiritual realm sanctions the moral obligations and responsibilities of the members of the community. These sanctions were very effective instruments for the enforcement of morality in traditional Yoruba society. The need to show that it is the responsibility of man, as a sensible being, to maintain the delicate balance between the two realms of existence has been a perennial concern for the Yoruba society.

\section{The implications of metaphysical presuppositions in punitive system for contemporary society}

The Yoruba are conscious of the fact that in most cases, whatever their actions and non-actions will be accounted for in the spiritual realm. This consciousness influences their daily moral practice. They believe that the wrongs ought to be appraised for their evilness, while the right actions are to be rewarded for their goodness. Therefore, according to their belief, the natural and spiritual realms must work in tandem to construct the ideal sense of punishment in Yoruba thought system. Besides, further justification of punishment in Yoruba ontology may generate out of the practice of cursing invoking the support and cooperation of specific gods. For example, a farmer may curse anyone who steals from his farm and by the invocation of the god's power inflict punishment on the thief. At other times, the victim of robbery would go to a shrine and ask a god to discipline the culprit in a particular fashion and would promise the god rewards for his benevolence. The culprit possessed by the god, perhaps by the Ayelala shrine, would make his way to the shrine and confess. Most 
often, a series of strange deaths may occur in the culprit's family (Adegbola, 1998, pp. 171-172). It is this existence of the invisible beings that play an overarching role in the justification of punishment, which engenders a standardised balance of social equilibrium in which genuine reconciliation between parties to a dispute, human well being, and social harmony are settled in the society. This enhances a 'collectivist approach to justice and fairness', to borrow Olaoba's words, whereby the principle of 'givea-little, get-a-little' is encouraged towards the restoration of harmony between litigants in such a way that there is 'no victor, no vanquished' adjudicatory system among the Yoruba (Olaoba, 2002, p. 47). The objective of this practice among the Yoruba is to construct an unbiased and fair system of justice among the community.

In the system, the spiritual realm takes up the adjudicatory responsibility when the administrators of justice face obstructions and difficulties during the course of trial cases. At this point, the accused is advised to swear the oath. The belief in the magical efficacy of oath could be well guaranteed. After the oath had been administered, the matter is left to the judgement of the gods of the land whom the people believe would bring misfortune to those who perjured themselves. Oath-taking is not only a mere solemn assertion of truth, which is synonymous with the western court; it is rather a type of self-imprecation, wherein the oath includes a punishing sanction as well. The oath invokes the names of some gods who are considered as dreadful or invokes the presence of sacred objects that possess magical powers symbolising the kind of punishment that might befall him if he swore falsely. But if misfortune befalls the oath-taker soon after the swearing, he would be pronounced guilty and the Yoruba society would condemn him.

The second is the conspicuous absence of emphasis on enforceability. As discussed earlier, the Yoruba tread cautiously before breaking the law of the land because of their ontological and moral conviction that a breach of the law would upset the entire ontological order. Okafor elucidates the philosophy underlying this phenomenon in his comparative analysis between the western conceptualisations of legal positivism and the traditional African practice, the separability thesis, and the non-separability thesis 
respectively. Okafor posits that legal positivism is 'a theory which recognises as valid laws only such enforceable norms as are enacted or established by the instrument of the state' (1984, p. 157). It implies that only strictly representational 'command' of a recognised authority is the law. The 'command', according to Okafor (1984, p. 159) quoting the Austinian imperativist's school, involves:

i. A wish or desire conceived by a rational being, that another rational being shall do or forebear.

ii. An evil to proceed from the former, and to be incurred by the latter, in case the latter comply not with the wish

iii. An expression or information of the wish by words or other signs.

It implies that the command is an order grounded on the threat by the sovereign which is to be obeyed by his / her subjects. It strictly excludes the 'positive morality', 'divine laws' and 'laws laid down by private individuals and institutions' (Okafor, 1984, p. 159).

Obviously, legal positivism is enmeshed in the separability thesis whereby positive laws, moral and teleological considerations are sheaved away. Okafor instead confines the traditional Sub-Sahara African experience to the non-separability thesis where laws are sourced from the ontological practice whereby both human and divine laws are noted and collapsed with the intent of a peaceful and harmonious human existence in the society. Divine laws represent the exclusive wish of the supernatural being and its breach is regarded 'as an offense not against man or human society but directly against the supreme Being' (Okafor, 1984, p. 160). Human laws, on the other hand, "are those laws relating to the economic, social and political life of the community. Their breach is considered less severe and the offender liable to public obloquy" (Okafor, 1984, p. 160).

Nevertheless, Okafor justifies that this jurisprudence, grounded in the ontological framework, features the belief that decision making is collectively based in as much as the 'concept of the sovereign' and another distinctive feature of African culture 'which recognise only leaders and not rulers, seniors but not superiors'. The laws so 
made are, therefore, ordinances of reason (and), not command' (Okafor, 1984, p. 162).

The relevance of the ancestors is not underrated in his proof. Okafor shows that the African creeds underwrite the African positive laws which do not contradict the tradition of the ancestors. The ancestors are responsible to transmit 'codes of moral conduct handed down from generation to generation'. This shows that "for African positive law to be a valid law, it must be seen as morally adequate" (Okafor, 1984, p. 162). Nwakeze (1987, p. 103) compliments that the Sub-Sahara African legal tradition "duly takes into cognisance the survival of the community through the amicable settlement of disputes, acceptable to all parties concerned. Thus, the role which these African legal systems play is basically reconciliatory".

It is noteworthy to emphasise that collective conscience saves it all in African juristic practice. So, the positivistic demand for enforceability mentioned earlier is a mirage in African jurisprudence. Rather, sanction with less force characterises the legal practice. It implies that law and order are maintained without regard for enforcement agents in as much as decisions are conscientiously taken and, attempts to contravene them is meted with the wrath of the ancestors and supernatural disfavour. Okafor (1984, p. 163) stresses that 'these are the lively consideration and conviction which bind the African's conscience and dispose him to obey the law whether or not there is a permanent or ad hoc power to enforce the law'.

To this end, it implies that justice is realistic in Sub-Sahara African legal experience to mainly promote and protect the interest of the community. Nwakeze (1987, p. 103) adds an oft-quoted line in Holleman's Issues in African law,

That the relations between man and his fellowmen are not governed by law alone, hence in the determination of a lawsuit law is not taken as the only determining factor. The whole social setting and relationship of the parties and their position in the community are taken into consideration; and in the interest of justice 'legal rules' are sometimes thrown overboard. 
It is a belief that to upset the ontological social order is to provoke dangerous reprisals to fall, not only upon the culprit but the whole community of which one is a member. It shows then that the Yoruba society will always experience a considerable set back whenever offenses are committed. The ontological advocates for punishment do not consider this force as a serious and adequate deterrent to deviant behaviour in Yoruba society. In this respect, punishment is proportionate to the crime as the Yoruba do not hesitate to say ika tío' se ni oba n'gé (Literally, it is the finger that cuts that offends the king) (Ajibola, 1977, p. 21 and p. 79) to buttress further the fact that the innocent person should not be punished. The Yoruba belief is that it is he who commits a crime that should be punished and sanctioned. And, whoever commits a crime cannot escape no matter how long he hides. Even, after he admits his wrongdoing and is punished for that he remains in people's memories as a wrongdoer. Hence the submission of being discharged and acquitted in western penology, where the trial cases are assumed to be both inconclusive and lacking merit, is not synonymous with this punitive experience. Rather, in an importance sense, the influence of metaphysical presuppositions recognises and incorporates the salience of oath-taking practices in both civil and criminal matters. It indicates that the issue of 'justice delayed is justice denied' does not reflect in the Yoruba penal system. The adjudicatory services in the contemporary justice system are overwhelmed by repetitive adjournments. It is noteworthy that the delay in pronouncement on cases is in most cases due to the absence or the lack or, cautions of concrete evidences which is not a barrier with the punishment practices in the Yoruba penology. In equal vein, the congestion of prisons and its adjournment of cases by trial judges in the contemporary situation are avoidable instances seen from the perspective of the traditional Yoruba adjudicatory system. This further touches on the conscience of those involved in the dispensation of justice, a proven challenge to the adjudicatory system in contemporary society.

\section{Conclusion}

In the analysis given above, based on the significance of metaphysical presuppositions in Yoruba culture, it has been shown 
that the Yoruba believe in a continuity of life and a community of interest between the two realms of existence. For them, conflicts are a part of life which must not be allowed to be resolved by individual parties lest they disrupt the social order. A strong sense of sanction is meted to the individual who acts or contravenes the common good of the community and its values despite the protection of individual interests. It emphasises the judicious imposition of punishment on the offender as a means of establishing responsibility for human actions rather than disproportional gravitation of punishment which may degenerate into further antagonism and animosity. Above all, this idea of social control system evolved out of the unity of the cosmos orientation, which encouraged the rebirth of African belief in human being as capable of change and, therefore, deserves a second chance rather than the alien idea of punitive practises of victimisation inherited by the Sub-Sahara African state criminal justice system.

Also, we have realised that the impact of metaphysical presuppositions on the punitive system would provoke the belief that he who commits a crime should be punished proportionately. So, the punishment of the innocent in any given dispute or circumstance is frowned at. That is the reason why the oath-taking practice is embarked upon in order to exhaustively root the heart of a case, especially when the issue hinges on complicated and complex grounds. It is believed that when the innocent is punished unjustly for a crime that was committed by another, the consequences for the society could be deadly and grave. In fact, punitive measures are not treated at prima-facie level, but rather transcend the immediate offenders on to the family and community where the offender is necessarily a member. It is noteworthy here that the traditional institution of legal-system is particular about the disapproval of wrongdoing rather than the punishment of wrong-doer. Thus, collaborative efforts, as a process of justicemaking, make it an opportunity for dialogue amongst the victim, offender, the family and friends, and the community. As such, all complaints and issues relevant to the case are harmoniously resolved for the well-being of the community. 
It is important to note here that the states of criminal-justice-system in this region of Africa be retracted constructively towards embracing the traditional institution practices, grounded in metaphysical presuppositions, rather than the continual celebration of formal and disengaged nature of justice. This will undoubtedly address an essential element in the dispensation of justice in a swift, efficient manner in the contemporary society.

\section{References}

Abimbola, K. (2006). Yoruba culture: A philosophical account. Birmingham: Iroko Academic Publishers.

Adegbola A.E .A . (Ed.). (1998). Traditional religion in west Africa. Ibadan: Sefer

Ajibola, J. O. (1977). Owe Yoruba. Ibadan : Oxford University Press.

Ajisafe, E. A. (1946). The laws and customs of the Yoruba people. Abeokuta: Fola Bookshops.

Gbadegesin, S. (1984). Destiny, personality and the ultimate reality of human existence: A Yoruba Perspective. Ultimate Reality and Meaning, 7(3), 173-188.

Idowu, E. B. (1996). Olodumare: God in Yoruba belief. Ikeja: Longman Group Ltd.

Makinde, M.A. (1985). A philosophical analysis of the Yoruba concepts of Ori and human destiny. International Studies in Philosophy, 17(1), 5369.

Nwakeze, P.C. (1987). A critique of Olufemi Taiwo's criticism of legal positivism and African legal tradition. International Philosophical Quarterly, xxvii(1), 101-105.

Okafor, F. U. (1984). Legal positivism and the African legal tradition. International Philosophical Quarterly, 24(2), 157-164.

Oladipo, O. (1992). The idea of African philosophy. Ibadan: Molecular Press

Oladipo, O. (1992). The Yoruba conception of a person: An analyticophilosophical study. International Studies in Philosophy, XXIV(3), 15-24.

Olaoba, O. B. (2002). Yoruba legal culture. Ibadan: FOP Press.

Simpson, G.E. (1994). Yoruba religion and medicine in Ibadan. Ibadan: Ibadan University Press.

Sodipo, O. (2004). Notes on the concept of cause and chance in Yoruba traditional thought. In A. Fadahunsi \& O. Oladipo (Eds). Philosophy and the African prospect: Selected essays of Professor J. Olubi Sodipo on philosophy, culture and society. Ibadan: Hope Publications. 